\title{
Prevalence of bacterial vaginosis in females in the reproductive age group in Kadur, Karnataka, India
}

\author{
Akshita R. Seth, Chaitra S.*, Vaishnavi S., Sharath Chandra G. R.
}

Department of Obstetrics and Gynecology, ESIC PGIMSR Medical College, Bangalore, Karnataka, India

Received: 22 September 2017

Accepted: 26 September 2017

\section{*Correspondence:}

Dr. Chaitra S.,

E-mail: chaittra.shiv@gmail.com

Copyright: (C) the author(s), publisher and licensee Medip Academy. This is an open-access article distributed under the terms of the Creative Commons Attribution Non-Commercial License, which permits unrestricted non-commercial use, distribution, and reproduction in any medium, provided the original work is properly cited.

\begin{abstract}
Background: Bacterial vaginosis, well known as the nonspecific vaginitis is caused by the normal resident flora of the vagina, predominantly by the peroxides producing lactobacillus species, when there is a disparity in their proportion and replaced by Gardinerella vaginalis, Mycoplasm hominis, Mobilunceus species, Bacteroids species, Prevotela species, Fusobacterium species and Porphyromonus species, Peptostreptococcus species.

Methods: A cross section study was performed to study the prevalence of bacterial vaginosis in the reproductive age group women and the associated risk factors. The diagnosis of the vaginosis was made from the smear and Amsle's clinical criteria.

Results: Out of 250 patients $112(44.8 \%)$ were diagnosed to have BV, 20-29-year age group had the largest percentage of infection $69(61.6 \%)$. IUCD users $36(32.14 \%)$ are found to be suffering from BV. Vaginal candidiasis, trichomonas vaginalis and atypical cell of unknown significant was seen in $32(28.5 \%), 9(8.03 \%)$ and $17(15.17 \%)$ women respectively.

Conclusions: A routine high vaginal swab for smear and culture must be performed for every woman presenting with chronic white discharge and itching, to prevent misuse usage of antibiotic. Further studies are needed to study the associated risk factors for BV.
\end{abstract}

Keywords: Bacterial vaginosis, Intrauterine contraceptive device, Prevalence, Reproductive age group

\section{INTRODUCTION}

In the sexually transmitted infections, which poses to be a major public health problem in developing country likes our bacterial vaginosis contributes to as much as $40-50 \%$ by itself. ${ }^{1}$ Every minute there is a growth of the sexually transmitted disease and diagnosing them at an early stage and treating them remains a major challenge in a developing country like ours.

The burden of the disease is mainly in the underprivileged population, due to lack of knowledge and widening health facility within the populations. Globally it is estimated that 36 million adults are infected with gonorrhoea, syphilis, trichomoniasis, chlamydia and genital herpes. ${ }^{2,3}$ Bacterial vaginosis is the commonest cause of abnormal vaginal discharges in the reproductive age group women and also has a strong association with preterm labor, preterm premature rupture of membranes and low birth weight. ${ }^{4,5}$ Multiple study has found that there is a strong association between sexually transmitted infections (STIs) and early age of first intercourse and multiple sexual partners. ${ }^{6,7}$

Discharge from the vagina is a normal phenomenon to maintain the normal vaginal flora and environment, normal vaginal discharge is clear or milky with no foul smell. Whereas an abnormal discharge there is an altered color, amount, associated with itching/ malodor, which is caused by the alteration in the normal vaginal flora. 
Unsafe habits of overusing vaginal douching, sprays, bubble bath, antibiotics, steroids, abnormal sugar levels lead to the alteration of the normal flora. ${ }^{8}$ This study was conducted the study the prevalence of bacterial vaginosis among the reproductive age group women, in the rural population of Kadur, the associated risk factors and associated vaginal infections and the organisms causing it.

\section{METHODS}

We conducted a community based cross sectional study, on all the women residing in Kadar taluk. The study was conducted in March 2017, over a period of 7 days. Following a verbal consent of all the women in their reproductive age group who presented with complains of chronic white discharge. We collected basic patient like name, age, parity, marital history, potential risk factors were all collected in the questioner. A total of 120 women were examined, who were all sexually active, between the age group 16 to 40 years were included in the study.

Following a complete general examination, per abdomen examination and pelvic examination was performed. For the diagnosis, the Nugent's scoring of gram staining was used. Laboratory investigations were completed in the Kadar pathology labs and diagnostics, Kadar. Data was analyzed using the SPSS version 20.0.

\section{RESULTS}

Of the total 250 women who were enrolled in the study $112(44.8 \%)$ of the women had a positive result.

Table 1: Characteristics of the women.

\begin{tabular}{|lll|}
\hline Characteristic & Patients & Percentage \\
\hline Age & & \\
\hline$<19$ & 32 & 28.57 \\
\hline $20-24$ & 56 & 50 \\
\hline $25-29$ & 13 & 11.6 \\
\hline$\geq 30$ & 11 & 9.8 \\
\hline Parity & & \\
\hline Nulligravida & 14 & 12.5 \\
\hline $1-3$ & 94 & 83.9 \\
\hline$>3$ & 4 & 3.5 \\
\hline History of abortion & 34 & 30.3 \\
\hline PID & 46 & 41.07 \\
\hline STD & 23 & 20.5 \\
\hline Contraceptive usage & & \\
\hline Condom & 46 & 41.07 \\
\hline IUCD & 36 & 32.14 \\
\hline OCP & 5 & 4.46 \\
\hline Injectablable hormones & 0 & 0 \\
\hline Habits & & \\
\hline Tobacco chewing & 29 & 25.8 \\
\hline Smoking & 2 & 1.7 \\
\hline Alcoholism & 12 & 10.71 \\
\hline & & \\
\hline
\end{tabular}

$50 \%$ of the women were between the age group 20-24 years of age, $87.4 \%$ of the women were married and had at least one child. Previous history of abortion, pelvic organs infection and other sexually transmitted infection was seen in $30.3 \%, 41.07 \%$ and $20.5 \%$ respectively. $41.07 \%$ of the women gave history of using barrier method of contraception.

Vaginal discharge collected was smeared on glass slides, dried, heat fixed followed by staining with Gram's staining. The bacterial morph type was studied using the following scheme: 1+, 30 per field. Large Gram-positive rods were lactobacillus morphotypes; small Gramnegative to Gram-variable rods were considered as $G$. vaginalis and Bacteroides spp. morphotypes; curved Gram variable rods were considered as Mobiluncus spp. morphotypes.

Table 2: Nugents scoring of gram staining diagnosis of BV.

\begin{tabular}{|lll|}
\hline Nugents scoring & Positive patients & Percentage \\
\hline BV & 112 & 44.8 \\
\hline Intermediate & 34 & 13.6 \\
\hline Normal & 104 & 41.6 \\
\hline
\end{tabular}

0-3 = Normal, 4-6 = Intermediate, 7-10 = BV

Associated with bacterial vaginosis was candidiasis, which was seen in $28.5 \%$ of the women, followed by trichomonas's in $8.03 \%$ of the women. In concurrence with other studies candidiasis was the commonest associated infection, and was with white discharge for more than 6 months.

Table 3: Association between bacterial vaginosis and presence of other laboratory confirmed sexually transmitted or reproductive tract infections.

\begin{tabular}{|lll|}
\hline Organisms & Positive patients & Percentage \\
\hline Trichomoniasis & 9 & 8.03 \\
\hline Candiadiasis & 32 & 28.5 \\
\hline HIV infection & 1 & 0.89 \\
\hline Syphilis & 8 & 7.14 \\
\hline Gonorrhea & 0 & 0 \\
\hline
\end{tabular}

\section{DISCUSSION}

There has been multiple study performed in various parts of India on the prevalence of bacterial vaginosis. The prevalence of in our study was $44.8 \%$ which was much higher than the study conducted previously by Sangeeta et al $(40.66 \%)$ and in bardados $(33 \%) .{ }^{9,10}$ Various other studies have been reported between $25.4 \%$ to $38.6 \% .^{11}$

In present study, there was a statistically significant association between the parity of the women the prevalence of bacterial vaginosis. Amsel et al reported that in women using intrauterine contraceptive device there was a higher prevalence. ${ }^{12}$ In present study, we found $32.14 \%$ IUCD user had bacterial vaginosis. 
Many a times a vaginal discharged is made un noticed as not a major health problem, for which a woman does not seek treatment, in rural India due to lack of facilities. The real prevalence of the bacterial vaginosis may be under estimated in the study dude to a small sample size and also due to opt out of study of many women due to shyness. Bacterial vaginosis is an important health problem which may lead to intermenstrual bleed, prolonged menstrual bleeding, chronic itching and foul smelling discharge and chronic lower back pain. Serious morbidity like associated HIV and HPV infection and carcinoma in situ were unaware by the study population. Vaginal candidiasis in our study was $28.5 \%$ and higher than trichomoniasis like the same found in Watcharotone et al. ${ }^{13}$

\section{CONCLUSION}

The study shows us the high prevalence of Bacterial Vaginosis. There was significant association between the parity, uterine manipulation, IUCD user, history of STD with bacterial vaginosis. Health education to the rural areas and need of routine pap smear needs to be emphasized to the women in the reproductive age group. The easy mode of diagnosis and treatment needs to be stressed on to prevent morbidities.

Funding: No funding sources Conflict of interest: None declared

Ethical approval: The study was approved by the Institutional Ethics Committee

\section{REFERENCES}

1. Spiegel CA. Bacterial vaginosis. Clin Microbiol Rev. 1991;4(4):485-502.

2. Amsel R, Totten PA, Spiegel CA, Chen KC, Eschenbach D, Holmes KK. Nonspecific vaginitis: diagnostic criteria and microbial and epidemiologic associations. Am J Med. 1983 Jan 1;74(1):14-22.

3. Atashili J, Poole C, Ndumbe PM, Adimora AA, Smith JS. Bacterial vaginosis and HIV acquisition: a meta-analysis of published studies. AIDS (London, England). 2008 Jul 31;22(12):1493.

4. Allsworth JE, Peipert JF. Prevalence of bacterial vaginosis: 2001-2004 national health and nutrition examination survey data. Obstet Gynecol. 2007 Jan 1;109(1):114-20.
5. Brotman RM, Klebanoff MA, Nansel TR, Yu KF, Andrews WW, Zhang J, Schwebke JR. Bacterial vaginosis assessed by gram stain and diminished colonization resistance to incident gonococcal, chlamydial, and trichomonal genital infection. J Infect Dis. 2010;202(12):1907-15.

6. Bukusi EA, Cohen CR, Meier AS, Waiyaki PG, Nguti R, Njeri JN et al. Bacterial vaginosis: risk factors among Kenyan women and their male partners. Sexually transmitted diseases. 2006 Jun;33(6):361-7.

7. Vishwanath S, Talwar V, Prasad R, Coyaji K, Elias CJ, de Zoysa I. Syndromic management of vaginal discharge among women in a reproductive health clinic in India. Sexually Transmitt Infect. 2000 Aug;76(4):303-6.

8. Freshwater D, Masiln-Prothero S. Blackwell's Nursing dictionary. $2^{\text {nd }}$ ed. Blackwell publishing Ltd 2005;642.

9. Jogi SR, Babbar K. Prevalence of bacterial vaginosis in sexually active females in Chhattisgarh Institute of Medical Sciences, Bilaspur, Chhattisgarh. Int J Reprod Contracept Obstet Gynecol. 2015;4:963-7.

10. Levett PN, Taruvinga M, Maheswaran K, Rotchell Y. Genital tract infections in sexually active women in Barbados. West Indian Med J. 1995;44:128-9.

11. Bhalla P, Chawla R, Garg S, Singh MM, Raina U, Bhalla $R$ et al. Prevalence of bacterial vaginosis among women in Delhi, India. Indian $\mathbf{J}$ Med Res. 2007; 125:167-72.

12. Amsel R, Totten PA, Spiegel CA, Chen KC, Eschenbach D, Holmes KK. Nonspecific vaginitis. Diagnostic criteria and microbial and epidemiologic associations. Am J Med. 1983 Jan;74(1):14-22.

13. Watcharotone W, Sirimai K, Kiriwat O, Nukoolkarn $\mathrm{P}$, Watcharaprapapong $\mathrm{O}$, Pibulmanee $\mathrm{S}$ et al. Prevalence of bacterial vaginosis in Thai women attending the family planning clinic, Siriraj Hospital. J Med Assoc Thai. 2004;87:1419-24.

Cite this article as: Seth AR, Chaitra S, Vaishnavi S, Chandra SGR. Prevalence of bacterial vaginosis in females in the reproductive age group in Kadur, Karnataka, India. Int J Reprod Contracept Obstet Gynecol 2017;6:4863-5. 